\title{
16S rRNA-Based Identification of a Glucan-Hyperproducing Weissella confusa
}

\author{
Shraddha Shukla and Arun Goyal \\ Department of Biotechnology, Indian Institute of Technology Guwahati, Guwahati 781039, Assam, India \\ Correspondence should be addressed to Arun Goyal, arungoyl@iitg.ernet.in
}

Received 31 December 2010; Accepted 21 January 2011

Academic Editor: Alane Beatriz Vermelho

Copyright ( $) 2011$ S. Shukla and A. Goyal. This is an open access article distributed under the Creative Commons Attribution License, which permits unrestricted use, distribution, and reproduction in any medium, provided the original work is properly cited.

A gram-positive, nonmotile, irregular, short, rod-shaped new strain of Weissella confusa bacterium was isolated from fermented cabbage. The isolate was physiologically and biochemically characterised. The $16 \mathrm{~S}$ rDNA was amplified by polymerase chain reaction (PCR). The isolate was identified as Weissella confusa (GenBank accession number: GU138518.1) based on nucleotide homology and phylogenetic analysis. The isolate produces glucansucrase when grown in sucrose-supplemented culture medium which catalyses glucan formation. This novel isolate possesses high capacity of industrial use due to its high productivity of glucan $(34 \mathrm{mg} / \mathrm{mL})$ as compared to other strains reported. The optimum temperature for glucansucrase production was $25^{\circ} \mathrm{C}$. The shaking condition gave an enzyme activity of $6.1 \mathrm{U} / \mathrm{mL}$ which was 1.5 times higher than that given by static condition $(4.1 \mathrm{U} / \mathrm{mL})$. The temperature $35^{\circ} \mathrm{C}, \mathrm{pH} 5.4$, and ionic strength $10-20 \mathrm{mM}$ were optimum for enzyme assay. This investigation unraveled the abundance of industrially valuable microflora of the north east India.

\section{Introduction}

The Weissella species are gram-positive, non-spore-forming, heterofermentative, nonmotile, and irregular or coccoid rodshaped organisms. Members of the genus Weissella have been isolated from a variety of sources, such as fresh vegetables, fermented silage, meat, or meat products. Several lactic acid bacteria belonging to the genera Weissella have been introduced to wheat sourdough baking for in situ production of exopolysaccharides [1]. Weissella kimchii PL9023 was selected as a prebiotic as it mostly produced hydrogen peroxide which inhibited the growth and adherence of vaginal isolates of Candida albicans, Escherichia coli, Staphylococcus aureus, and Streptococcus agalactiae [2]. Lactic acid bacteria (LAB) that produce dextrans include various Leuconostoc, Streptococcus, and Lactobacillus species [3]. Smitinont et al. [4] had emphasised on dextran-synthesizing ability of the Pediococcus genus. Patel et al. [5] reported the dextranproduction ability of Pediococcus pentosaceus for the first time. Additionally, dextran production has typically served as a phenotypic test in the identification of bacteria classified in the genus Weissella [6]. Maina et al. [7] reported industrially useful dextran-producing Weissella confusa E392 which could be a suitable alternative to the widely used L. mesenteroides $\mathrm{B} 512 \mathrm{~F}$ in the production of linear dextran.

First proposed by Collins et al. [6] on the basis of the results of $16 \mathrm{~S}$ rDNA phylogenetic analyses, the genus Weissella encompasses a phylogenetically coherent group of lactic acid bacteria and includes twelve validated Leuconostoc-like species, currently, including W. confusa (formerly Lactobacillus confusus), W. minor (formerly Lactobacillus minor), W. kandleri (formerly Lactobacillus kandleri), W. halotolerans (formerly Lactobacillus halotolerans), W. viridescens (formerly Lactobacillus viridescens), Weissella paramesenteroides (formerly Leuconostoc paramesenteroides), W. hellenica, W. thailandensis, W. cibaria, Weissella kimchii, Weissella soil, and Weissella koreensis. Alternative molecular biological approaches have been developed in place of classical phenotypic methods for the identification of Weissella species. Such methods include soluble whole-cell protein pattern analyses [8], restriction pattern of ribosomal DNA [8] fatty acid analyses [9], random amplified polymorphic DNA-PCR (RAPD-PCR) [10], denaturing gradient gel electrophoresis (DGGE) [11], and PCR targeting 16S/23S 
rRNA gene spacer region [12]. In the present study, a novel Weissella species isolated from fermented cabbage was characterised up to genus and species level using $16 \mathrm{~S}$ rDNAbased sequence analyses. Its glucan formation capacity has been explored in detail and compared with that of Leuconostoc mesenteroides NRRL B-512F.

\section{Materials and Methods}

2.1. Isolation and Maintenance of Microorganism. Fresh chopped cabbage was subjected to fermentation in $2.5 \%$ $(\mathrm{w} / \mathrm{v}) \mathrm{NaCl}$ solution. One gram of fermented cabbage was ground to paste and mixed in $10 \mathrm{~mL}$ of saline $(0.9 \% \mathrm{w} / \mathrm{v})$ homogeneously in test tubes. The serial dilutions were made, till the dilution factor $10^{-5}$. One hundred microliter from all the dilutions of cabbage from $10^{-0}$ to $10^{-5}$ was taken and spread plated on petri plates of $1.7 \%(\mathrm{w} / \mathrm{v})$ MRS agar with glucose as carbon source [13]. Petri plates were incubated at $28^{\circ} \mathrm{C}$ for $24 \mathrm{~h}$. Based on the higher-glucansucrase activity and glucan concentration determined (as described later), a microbe Cab3 (named after its colony number) was isolated. The isolated bacterium was propagated as stab in MRS agar supplemented with sucrose as carbon source [14] at $25^{\circ} \mathrm{C}$ and stored at $4^{\circ} \mathrm{C}$. For long-term preservation, the isolate was kept in $20 \%(\mathrm{v} / \mathrm{v})$ glycerol at $-80^{\circ} \mathrm{C}$.

\subsection{Morphological, Physiological, and Biochemical Character-} ization. The colony morphology of isolates grown on MRS medium for overnight at $25^{\circ} \mathrm{C}$ was observed directly and by light microscopy. Cell mobility and gliding movement were assessed by phase-contrast microscopy (1000x) using cells of MRS broth. The Gram reaction was performed using the $\mathrm{KOH}$ method of Gregesen [15]. The cell morphology of the selected isolate was examined by scanning electron microscopy (Leo1430 VP, Leo Electron Microscopy Ltd., Cambridge, UK) operated at $10.0 \mathrm{kV}$. The catalase activity was determined by transferring fresh colonies from MRS agar to a drop of $5 \%(\mathrm{v} / \mathrm{v}) \mathrm{H}_{2} \mathrm{O}_{2}$ on a glass slide. For the temperature tolerance of the microorganism, the growth of selected isolate was carried out using MRS broth at different temperatures, that is, $4^{\circ} \mathrm{C}, 10^{\circ} \mathrm{C}, 15^{\circ} \mathrm{C}, 20^{\circ} \mathrm{C}, 30^{\circ} \mathrm{C}, 37^{\circ} \mathrm{C}$, and $42^{\circ} \mathrm{C}$ for 2 days. For salt tolerance of the isolate, the growth was observed using MRS broth in the presence of $4.0 \%$ and $6.5 \%(\mathrm{w} / \mathrm{v})$ of $\mathrm{NaCl}$ incubated at $25^{\circ} \mathrm{C}$ for $2 \mathrm{~d}$. The production of glucan (slimy layer) by isolate Cab3 from sucrose was observed on MRS agar in which glucose was replaced by sucrose [14].

The strain Cab3 was tested for its ability to ferment various carbohydrates using the method of Kandler and Weiss [21]. From the overnight-grown MRS broth containing $2 \%(\mathrm{w} / \mathrm{v})$ glucose as carbohydrate source, $50 \mu \mathrm{L}$ was inoculated in $5.0 \mathrm{~mL}$ liquid MRS medium lacking glucose but containing phenol red and other test carbohydrates to give a final inoculum to medium ratio of $1 \%(\mathrm{v} / \mathrm{v})$. The test media were incubated for 2 days at $30^{\circ} \mathrm{C}$ without shaking. The acid production was recorded between 24 and $48 \mathrm{~h}$. The acid production was indicated by a change in the colour of the phenol red indicator dye from red to yellow. The isolated strain cab3 was tested for susceptibility to 30 antibiotics using a standardized filter-paper disc-agar diffusion assay, to determine the drug susceptibility of microorganisms [22].

The antibiotic tests were performed using commercially available antibiotic octadiscs containing Amoxyclav (Ac), cephalexin (Cp), ciprofloxacin (Cf), clindamycin $(\mathrm{Cd})$, cloxacillin $(\mathrm{Cx})$, erythromycin $(\mathrm{E})$, tetracycline $(\mathrm{T})$, ampicillin (A), carbenicillin $(\mathrm{Cb})$, cefotaxime $(\mathrm{Ce})$, chloramphenicol $(\mathrm{C})$, co-Trimazine $(\mathrm{Cm})$, gentamicin $(\mathrm{G})$, norfloxacin $(\mathrm{Nx})$, oxacillin $(\mathrm{Ox})$, amikacin $(\mathrm{Ak})$, amoxycillin $(\mathrm{Am})$, bacitracin $(\mathrm{B})$, cephalothin $(\mathrm{Ch})$, novobiocin $(\mathrm{Nv})$, oxytetracycline $(\mathrm{O})$, vancomycin $(\mathrm{V})$, penicillin- $\mathrm{G}$ $(\mathrm{P})$, tobramycin $(\mathrm{Tb})$, cephaloridine $(\mathrm{Cr})$, kanamycin $(\mathrm{K})$, lincomycin (L), methicillin (M), norfloxacin (Nf), and oleandomycin $(\mathrm{Ol})$ from Hi-media Pvt. Ltd. India.

\section{3. $16 S$ rDNA-Based Sequence Analyses}

2.3.1. Extraction of Genomic DNA. The bacterial cell pellet was lysed using a solution containing guanidium thiocyanate (a chaotropic agent) and SDS (a detergent), to extract DNA [23]. This lysis solution was used to disrupt the cell, remove proteins and polysaccharides, and partial hydrolysis of RNA. The genomic DNA was extracted by GeNeiTM Genomic DNA Extraction kit (Bangalore Genei Pvt. Ltd.). DNA was then precipitated using alcohol and washed with $70 \%(\mathrm{v} / \mathrm{v})$ alcohol to remove contaminants. DNA pellet was solubilized in sodium acetate buffer at pH 5.5 added to a final concentration of $0.3 \mathrm{M}$ in isopropanol at higher temperature $\left(50-55^{\circ} \mathrm{C}\right)$, to increase the solubility of genomic DNA. The extracted DNA was purified using Ultrapure prep kit (KT83B, Bangalore Genei, India). Genomic DNA was purified in a gravity flow column using elution buffer, followed by treatment with lysozyme, proteinase $\mathrm{K}$, and RNase A supplied with the kit. DNA concentrations were determined in duplicate using a spectrophotometer. The quality of purified DNA was evaluated on 1.2\% Agarose gel, a single band of high-molecular-weight DNA was observed.

2.3.2. PCR Amplification. The genomic DNA of isolate Cab3 was used for amplification of $16 \mathrm{~S}$ rRNA gene. The universal 16S rDNA primers, forward primer 8F (5'AGTTGATCCTGGCTCAG3'), and reverse primer 1492R (5'ACCTTGTTACGACTT3') were used for the polymerase chain reaction (PCR). The PCR amplification was carried out in a reaction mixture containing $\sim 10 \mathrm{ng}$ genomic DNA as template, $1 \mu \mathrm{L}$ dNTP mix (2.5 mM each), $100 \mathrm{ng} / \mu \mathrm{L}$ each of forward and reverse primer, 1X Taq DNA polymerase assay buffer (10X), 3U Taq DNA polymerase enzyme (Bangalore Genei Ltd.,Bangalore, India), and distilled water enough to make up the volume to $50 \mu \mathrm{L}$ reaction mixture. Amplification conditions were $5 \mathrm{~min}$ initial denaturation at $94^{\circ} \mathrm{C}, 30 \mathrm{~s}$ denaturation at $94^{\circ} \mathrm{C}, 30 \mathrm{~s}$ of primer annealing at $54^{\circ} \mathrm{C}, 1 \mathrm{~min}$ elongation at $72^{\circ} \mathrm{C}$ for 35 cycles, and a final extension of $10 \mathrm{~min}$ at $72^{\circ} \mathrm{C}$. The reactions were carried out in a Thermal Cycler (Applied Biosystems, model ABI 2720). 
2.3.3. Electrophoresis and Sequencing of $16 S$ rRNA Gene. Fifteen $\mu \mathrm{L}$ of PCR amplified product was electrophoresed on $1.2 \%(\mathrm{w} / \mathrm{v})$ low-EEO agarose gel in 1X TBE buffer $(45 \mathrm{mM}$ Tris-borate, $\mathrm{pH} 8.3$, and $1 \mathrm{mM} \mathrm{Na} 2 \mathrm{EDTA}$ ) at $100 \mathrm{~V}$ for $2 \mathrm{~h}$. The gel was stained with ethidium bromide in a final concentration of $0.5 \mu \mathrm{g} / \mathrm{mL}$, visualized, and photographed under UV light. The amplified 16S rRNA gene from the isolate was eluted and purified from the gel slice using the GeneiPure TM Gel Extraction Kit (QIAGEN). Forward and reverse DNA sequencing reaction of PCR amplicon was carried out with $8 \mathrm{~F}$ and $1492 \mathrm{R}$ primers using BDT v3.1 Cycle sequencing kit on ABI 3730xl Genetic Analyzer. Consensus sequence of $1288 \mathrm{bp}$ of $16 \mathrm{~S} \mathrm{rDNA}$ gene was generated from forward and reverse sequence data using aligner software.

2.3.4. Sequence Alignment of $16 \mathrm{~S}$ rRNA Gene. The $16 \mathrm{~S}$ rDNA gene sequence of the isolate cab3 was used to carry out BLAST with the nr database of NCBI GenBank database. Based on maximum identity score, first ten sequences were selected and aligned using multiple alignment software program ClustalW. Distance matrix was generated using RDP database, and the phylogenetic tree was constructed using MEGA 4 [28].

\subsection{Production of Glucansucrase and Its Assay}

2.4.1. Enzyme Activity Assay. The enzyme assay was carried out in $1 \mathrm{~mL}$ reaction mixture containing $5 \%(\mathrm{w} / \mathrm{v})$ sucrose, $20 \mathrm{mM}$ sodium acetate buffer ( $\mathrm{pH} 5.4$ ), and $20 \mu \mathrm{L}$ cell-free supernatant. The enzymatic reaction was performed at $30^{\circ} \mathrm{C}$ for $15 \mathrm{~min} .100 \mu \mathrm{L}$ aliquot from the reaction mixture was taken for reducing sugar estimation. The enzyme activity was determined by estimating the released reducing sugar by Nelson [29] and Somogyi [30] method. The absorbance of the colour developed was measured by spectrophotometer at $500 \mathrm{~nm}$. Fructose was used to plot the standard graph.

2.4.2. Effect of Temperature on Enzyme Production. The glucansucrase was produced in the enzyme production medium as described by Tsuchiya et al. [31]. Fermentations were carried out in triplicate sets of $60 \mathrm{~mL}$ enzyme production medium in a $250 \mathrm{~mL}$ Erlenmeyer flask incubated at $25^{\circ} \mathrm{C}$ under shaking condition at $180 \mathrm{rpm}$. The samples $(1 \mathrm{~mL})$ were withdrawn at indicated time intervals and centrifuged at $8000 \mathrm{~g}$ for $10 \mathrm{~min}$ at $4^{\circ} \mathrm{C}$ to separate the cells. The cellfree supernatant was analyzed for enzyme activity. Weissella confusa was grown at various temperatures: $22^{\circ} \mathrm{C}, 25^{\circ} \mathrm{C}$, $28^{\circ} \mathrm{C}, 30^{\circ} \mathrm{C}, 32^{\circ} \mathrm{C}, 37^{\circ} \mathrm{C}$, and $40^{\circ} \mathrm{C}$ in the flasks as described previously in an orbital shaking incubator at $180 \mathrm{rpm}$ to determine the optimum incubation temperature for the maximum enzyme production. The culture $(1.0 \mathrm{~mL})$ was withdrawn at the indicated time intervals and centrifuged at $8000 \mathrm{~g}$ for $10 \mathrm{~min}$ at $4^{\circ} \mathrm{C}$ to pellet out the cells. The cell-free supernatant was analyzed for enzyme activity.

2.4.3. Effect of Shaken-Flask Culture on Enzyme Production. The production glucansucrase was compared under shakenflask condition with the static flask culture at $25^{\circ} \mathrm{C}$ in triplicate sets of $60 \mathrm{~mL}$ enzyme production medium in $250 \mathrm{~mL}$ Erlenmeyer flasks. The shaking was carried out in an orbital shaking incubator at $180 \mathrm{rpm}$. The samples $(1.0 \mathrm{~mL})$ were withdrawn at indicated time intervals and centrifuged at $8000 \mathrm{~g}$ for $10 \mathrm{~min}$ at $4^{\circ} \mathrm{C}$ to pellet out the cells. The cellfree extract was analysed for enzyme activity and protein concentration as described earlier.

2.4.4. Analysis of Glucan Content of the Isolated Strain. The polysaccharide content of the isolated strain (Cab3) was determined by phenol-sulphuric acid method [32] in a microtitre plate [33]. The isolated strain was grown in $60 \mathrm{~mL}$ liquid medium described by Tsuchiya et al. [31] at $25^{\circ} \mathrm{C}$ and $180 \mathrm{rpm}$ up to $32 \mathrm{~h}$. The samples $(1 \mathrm{~mL})$ were withdrawn at regular intervals. To $200 \mu \mathrm{L}$ of the culture supernatant, three volumes of the prechilled ethanol were added and centrifuged at 12,000 g. The supernatant was discarded, and the precipitate was resuspended in $200 \mu \mathrm{L}$ distilled water. The process was repeated two more times. The final precipitate was air dried and dissolved in $200 \mu \mathrm{L}$ distilled water. Dextran T-40 was used to plot the standard.

2.5. Purification and Identification of Glucansucrase by Activity Staining. The crude $50 \mathrm{~mL}$ cell-free supernatant with enzyme activity $6 \mathrm{U} / \mathrm{mL}$ and specific activity $1 \mathrm{U} / \mathrm{mg}$ was subjected to purification by fractionation using PEG-400 (33\%, $\mathrm{w} / \mathrm{v})$. The enzyme activity was determined as described earlier. The protein concentration was determined by the method of Lowry et al. [34]. To confirm the existence of glucansucrase, the PAS staining of the sucrose- and raffinoseincubated gel was carried out on 7\% nondenaturing SDSPAGE [35]. The electrophoresis was performed on a mini gel unit (BioRad) using $1.5 \mathrm{~mm}$ thick gels, following the method of [36]. After run, the gel was treated thrice with a solution containing $20 \mathrm{mM}$ sodium acetate buffer, $\mathrm{pH}$ 5.4, $0.1 \%(\mathrm{w} / \mathrm{v})$ Triton X-100, and $0.005 \%$ (w/v) calcium chloride for $20 \mathrm{~min}$ to remove SDS. Then, the gel was incubated with $5 \%(\mathrm{w} / \mathrm{v})$ sucrose/raffinose solution in $20 \mathrm{mM}$ sodium acetate buffer, pH 5.4 for $10-12 \mathrm{~h}$. Following incubation, the gel was washed twice with $75 \%(\mathrm{v} / \mathrm{v})$ ethanol for $20 \mathrm{~min}$ and incubated in solution with $0.7 \%(\mathrm{w} / \mathrm{v})$ periodic acid in $5 \%(\mathrm{v} / \mathrm{v})$ acetic acid for $20 \mathrm{~min}$ at room temperature. The gel was then washed thrice with $0.2 \%(\mathrm{w} / \mathrm{v})$ sodium bisulfate in $5 \%(\mathrm{v} / \mathrm{v})$ acetic acid solution and finally stained with Schiff's reagent $(0.5 \%$ $\mathrm{w} / \mathrm{v}$ basic fuchsin, $1 \%(\mathrm{w} / \mathrm{v})$ sodium bisulfate, and $0.1 \mathrm{~N} \mathrm{HCl})$ until the discrete magenta bands appeared within the gel.

\subsection{Effect of Temperature, $p H$, and Ionic Strength on Enzyme} Assay. The enzyme assay conditions were optimized to find maximum enzyme activity. The purified enzyme having $10.4 \mathrm{U} / \mathrm{mg}$ specific activity $(1.0 \mathrm{mg} / \mathrm{mL})$ was used for further optimization of assay conditions. The ionic strength of the buffer was varied from $10 \mathrm{mM}$ to $400 \mathrm{mM}$. The assay was carried out in $1 \mathrm{~mL}$ reaction mixture containing $5 \%(\mathrm{w} / \mathrm{v})$ final sucrose concentration, in sodium acetate buffer $(\mathrm{pH}$ 5.4) at $30^{\circ} \mathrm{C}$ for $15 \mathrm{~min}$. To study the effect of varied $\mathrm{pH}$ on enzyme activity, the $\mathrm{pH}$ of buffer was varied from 4 to 7 in $1 \mathrm{~mL}$ reaction mixture containing $5 \%(\mathrm{w} / \mathrm{v})$ final 
TABLE 1: Differential characteristics of Weissella confusa and other lactic acid bacteria.

\begin{tabular}{|c|c|c|c|c|c|c|c|c|c|c|}
\hline Characteristics & 1 & $2[24]$ & $3[21]$ & $4[21]$ & $5[6]$ & $6[25]$ & $7[26]$ & $8[18]$ & $9[27]$ & 10 [27] \\
\hline \multicolumn{11}{|l|}{ Acid from: } \\
\hline Ribose & + & + & + & + & - & - & + & NT & NT & NT \\
\hline D-Xylose & + & + & - & + & - & + & - & + & + & + \\
\hline Galactose & + & - & + & + & - & + & + & + & + & + \\
\hline D-Fructose & + & - & + & + & + & NT & - & + & + & + \\
\hline Cellobiose & + & - & - & + & - & + & - & + & - & + \\
\hline Melibiose & - & + & - & - & - & + & + & + & + & + \\
\hline Sucrose & + & + & - & + & + & + & $\mathrm{D}$ & + & + & + \\
\hline Trehalose & - & + & - & - & + & - & $\mathrm{D}$ & + & + & + \\
\hline D-Raffinose & - & + & - & - & - & - & + & + & + & - \\
\hline Maltose & + & NT & - & + & + & + & + & - & + & + \\
\hline Dextran formation & + & - & + & + & - & + & - & + & + & + \\
\hline Cell morphology & $\begin{array}{l}\text { Short } \\
\text { rods }\end{array}$ & $\begin{array}{l}\text { Short } \\
\text { rods, often } \\
\text { thickened } \\
\text { to one end }\end{array}$ & $\begin{array}{l}\text { Irregular } \\
\text { rods }\end{array}$ & $\begin{array}{l}\text { Short rods, } \\
\text { thickened } \\
\text { at one end }\end{array}$ & $\begin{array}{l}\text { Large } \\
\text { spherical or } \\
\text { lenticular } \\
\text { cells }\end{array}$ & NT & Spherical & $\begin{array}{l}\text { Cocci-shaped } \\
\text { and random } \\
\text { arrangement in } \\
\text { groups or chains }\end{array}$ & NT & NT \\
\hline
\end{tabular}

1, W. confusa (Cab3) 2, W. soli; 3, W. kandleri; 4, W. confusa; 5, W. hellenica; 6, W. kimchii; 7, W. thailandensis; 8, P. pentosaceus; 9, L. mesenteroides B-512F; 10, L. mesenteroides B-640. Symbols: +, $90 \%$ or more strains were positive; -, $90 \%$ or more strains were negative; D, 11-89\% of strains were positive; NT, not tested.

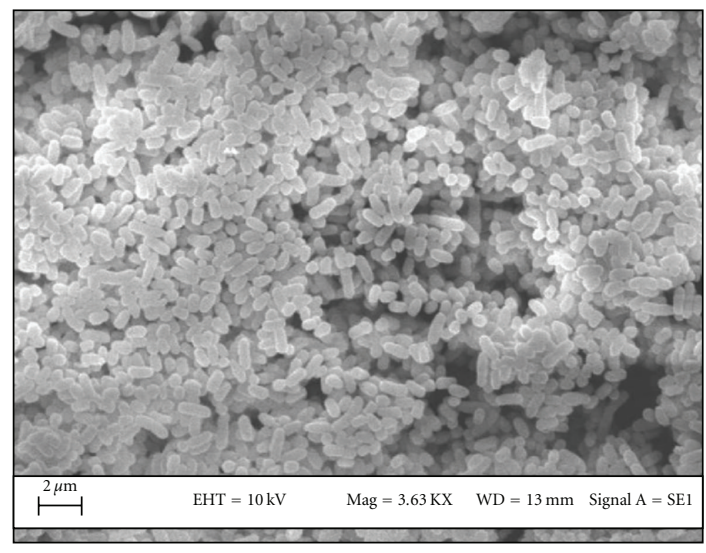

FIGURE 1: Scanning electron microscopic image of Weissella confusa.

sucrose concentration in $20 \mathrm{mM}$ sodium acetate buffer at $30^{\circ} \mathrm{C}$ for $15 \mathrm{~min}$. The enzyme assay was performed within the temperature range of $20^{\circ} \mathrm{C}$ to $50^{\circ} \mathrm{C}$. The enzyme assay was done in $5 \%(\mathrm{w} / \mathrm{v})$ sucrose solution in $20 \mathrm{mM}$ sodium acetate buffer ( $\mathrm{pH}$ 5.4) for $15 \mathrm{~min}$.

\section{Results and Discussion}

3.1. Isolation, Morphological, Phenotypic, and Chemotaxonomic Characterization of Isolate Cab3. Based on higher glucansucrase activity and glucan concentration determined, a microbe Cab3 was isolated from the fermented cabbage. The isolated culture was identified according to their morphological, cultural, physiological, and biochemical characteristics
$[37,38]$. The tests used were gram reaction, production of catalase and growth at different temperatures and salt concentrations, and acid production from carbohydrates $(2 \%$ w/v). W. confusa can be identified and differentiated from other species such as Enterococcus spp., Streptococcus spp., Lactococcus spp., and Leuconostoc spp. by its biochemical and physiological properties like arginine deamination, esculin hydrolysis, growth at $42^{\circ} \mathrm{C}$, and acidification of certain carbohydrates [39]. The results of both physiological and biochemical tests are shown in Table 1. The microorganism was identified by comparing the results with those from the literature (Table 1). The results of the comparison showed that the isolated strain Cab3 has the same characteristics as $W$. confusa (Table 1, Column 5, which is, 4 [21]). From scanning electron microscopy, the isolate Cab3 was found to be phenotypically homogeneous with irregular short rod cells in pairs or chains with a width and length of 0.5 $0.6 \mu \mathrm{m}$ and $1.2-1.4 \mu \mathrm{m}$, respectively (Figure 1 ). The colonies on MRS agar medium were opaque, circular, and slightly convex. The isolate showed Gram-positive, catalase-negative, and nonmotile characteristics. The isolate showed growth between 15 and $42^{\circ} \mathrm{C}$. The colony produced slimy layer when grown on MRS agar plate was supplemented with sucrose. The strain could grow in presence of $4.0 \%, 5.0 \%, 6.0 \%$, and $6.5 \%(\mathrm{w} / \mathrm{v}) \mathrm{NaCl}$, but not beyond $8.0 \% \mathrm{NaCl}$. The strain very efficiently utilised cellobiose, galactose, maltose, ribose, sucrose, and xylose but poorly fermented mellibiose, raffinose, and trehalose which was in accordance with fermentation pattern of Weissella confusa reported earlier [40]. The Cab3 did not utilize rhamnose which is also characteristic of Weissella sp. [39]. The isolate Cab3 was sensitive to chloramphenicol, erythromycin, and tetracycline 


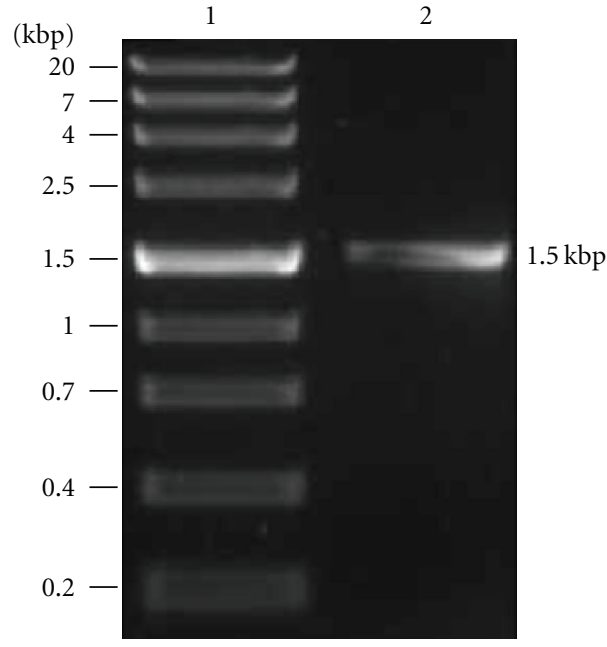

Figure 2: Full-length $16 \mathrm{~S}$ rRNA gene (1500 bp) of the isolate cab3 amplified with universal primers. The amplicon was electrophoretically resolved on a 1.2\% agarose gel in $1 \mathrm{X}$ TBE buffer (a) Lane1: DNA ladder (b) Lane 2: amplified product of full length 16S rRNA gene.

and moderately resistant to gentamicin, kanamycin, norfloxacin, and vancomycin which is characteristic of Weissella confusa [40].

3.2. 16S rDNA Sequence Analyses. 16S rRNA gene sequence analyses after PCR amplification was performed for identifying the isolate Cab3. The profiles obtained by PCR amplification allowed the identification of the isolate at both genus and species levels. The amplified product of $16 \mathrm{~S}$ rRNA showed a single band of 1,500 bp (Figure 2). Forward and reverse DNA sequencing reaction of PCR amplicon was carried out with $8 \mathrm{~F}$ and $1492 \mathrm{R}$ primers using BDT v3.1 Cycle sequencing kit on ABI 3730xl Genetic Analyzer. The consensus sequence of $1288 \mathrm{bp}$ of $16 \mathrm{~S}$ rDNA gene was generated from forward and reverse sequence data using aligner software (Figure 3). The 16S rRNA sequence was compared with reference bacteria from the National Centre for Biotechnological Information (NCBI) Genbank (http:// www.ncbi.nlm.nih.gov/) and Ribosomal Database Project (RDP). Similarity searches were carried out using the BLAST algorithms available at (http://www.ncbi.nlm.nih.gov/blast). Multiple sequence alignment was performed using ClustalW (http://www.ebi.ac.uk/clustalw) [41]. The alignment was checked visually and corrected manually using the sequence editor. The homology in sequences identified by the above methods was used to find out common ancestry. The evolutionary history was inferred using the neighbor-joining method [42]. The bootstrap consensus tree inferred from 500 replicates was taken to represent the evolutionary history of the taxa analyzed [43]. Branches corresponding to partitions reproduced in less than $50 \%$ bootstrap replicates are collapsed. The percentage of replicate trees in which the associated taxa clustered together in the bootstrap test (500 replicates) is shown next to the branches [43]. The evolutionary distances were computed using the Kimura 2parameter method [44] and are in the units of the number of base substitutions per site. Codon positions included were $1 \mathrm{st}+2 \mathrm{nd}+3 \mathrm{rd}+$ noncoding. All positions containing gaps and missing data were eliminated from the dataset (complete-deletion option). There were a total of 1288 positions in the final dataset. Phylogenetic analyses were conducted in MEGA4 [28]. The isolate cab3 and the strain Weissella confusa IMAU:10190 (Genbank accession number GU 138518.1) clustered together (Figure 4) which confirmed the isolate to be Weissella confusa. Hence, the isolate cab3 was identified as Weissella confusa and assigned the Genbank accession number GU138518.1. A bioinformatic tool, GeneDoc software, version 2.7.1, was used for more $16 \mathrm{~S}$ rRNA gene sequence investigation of the other closely related Weissella sp. The partial sequence (1288 nucleotides) of $16 \mathrm{~S}$ rDNA of Weissella confusa (Cab3) was 100\% similar to 16S rRNA genes from other related strains of Weissella sp. in NCBI (Figure 3).

\subsection{Production of Glucansucrase under Different Culture Conditions}

3.3.1. Effect of Temperature. Temperatures ranging from $22^{\circ} \mathrm{C}$ to $40^{\circ} \mathrm{C}$ were studied for the production of enzyme under shaking at $180 \mathrm{rpm}$ (Figure 5). At $25^{\circ} \mathrm{C}$, the activity achieved was maximum $(6.2 \mathrm{U} / \mathrm{mL})$, at a temperature lower than $25^{\circ} \mathrm{C}$, the cell growth was slow which might be the cause for lower enzyme activity as shown in Figure 5. At higher temperature, the enzyme activity decreased which might be due to the deactivation of the enzyme at higher temperatures.

3.3.2. Effect of Shaken-Flask Culture. Shaking condition significantly favoured the enzyme production giving $6.1 \mathrm{U} / \mathrm{mL}$ enzyme activity which was 1.5 times higher than the enzyme activity observed under static condition $(4.1 \mathrm{U} / \mathrm{mL})$ as shown in Figure 6. The maximum enzyme activity was achieved $4 \mathrm{~h}$ later in case of static flask culture. Figure 7 shows a complete fermentation profile of the new strain of Weissella confusa (Cab3). The enzyme production and glucan production were cell growth associated. The fermentation profile of the new strain of Weissella confusa (Cab3) was compared with other lactic acid bacterial strains using the same medium composition and the parameters compared are listed in Table 2. It was reported that $23^{\circ} \mathrm{C}$ temperature under static flask culture condition was optimum for the production of dextransucrase from L. mesenteroides NRRL B-512F [16], and $25^{\circ} \mathrm{C}$ temperature under shaking condition was found to be optimum for L. mesenteroides NRRL B-640, whereas, for Weissella confuse, the temperature $25^{\circ} \mathrm{C}$ and shaking conditions were optimum. From the results, it was clear that the enzyme activity $(6.1 \mathrm{U} / \mathrm{mL})$ from Weissella confusa was $50 \%, 27 \%$, and $65 \%$ higher than the enzyme activity from L. mesenteroides NRRL B-512F (4.1 U/mL), L. mesenteroides NRRL B-640 (4.8 U/mL), and P. pentosaceus, respectively, as shown in Table 2 . The cell growth obtained in all strains after $12 \mathrm{~h}$ was similar. There was a sharp decrease in the 

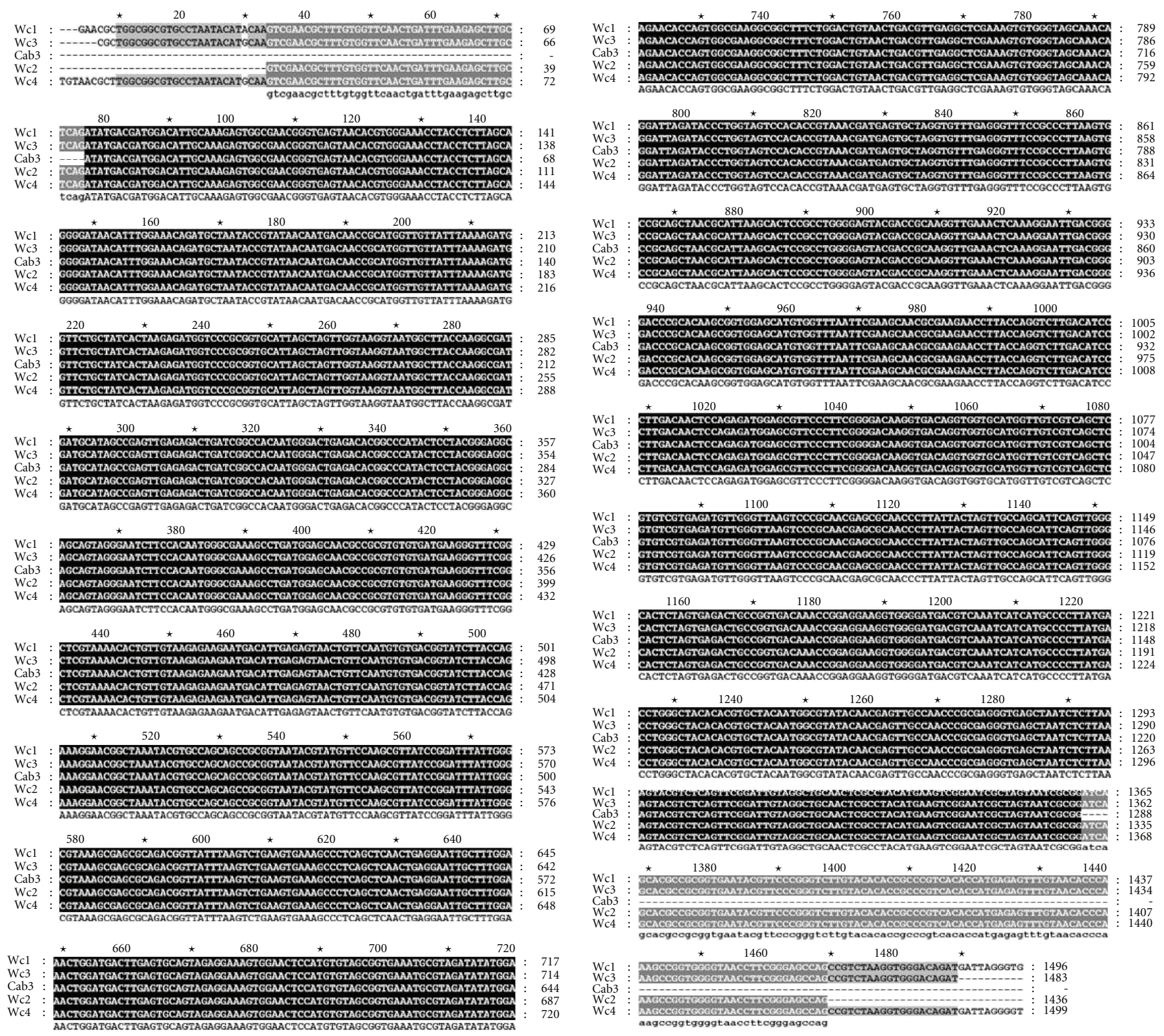

\section{Wc1
Wc3
Cab3
Wc2
Wc4

Wc1
Wc3
Wab3
Wc2
Wc4}

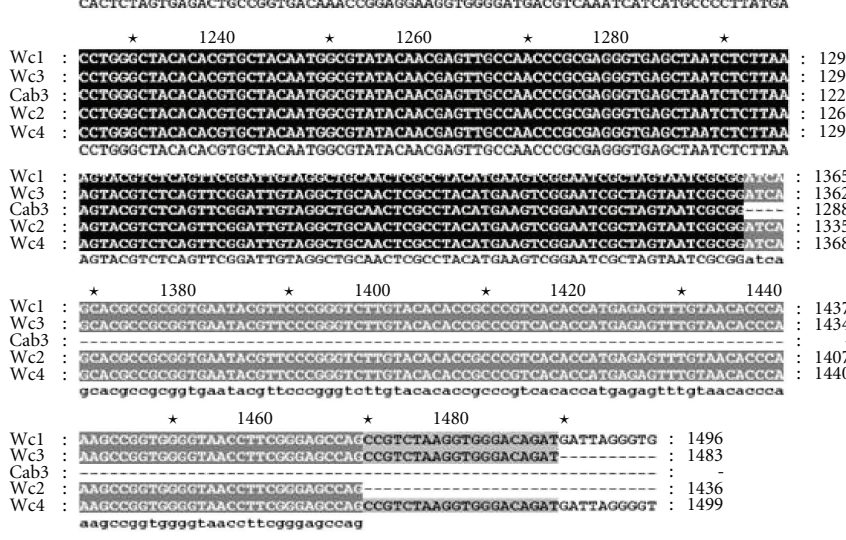

FIGURE 3: 16S rRNA gene sequence investigation of Weissella confusa (Cab3) by bioinformatics tool, GeneDoc software version 2.7.1. W.c1:W.c_IMAU:10190, W.c2: W.c strain _JS-9-2, W.c3: W.c_IMAU:10264, W.c4: W.c_IMAU:10271, Cab3: isolated strain.

$\mathrm{pH}$ of the broth with Weissella confusa after $12 \mathrm{~h}$ (Figure 7), when the maximum activity was achieved, whereas the $\mathrm{pH}$ drop was much lower from the point where the maximum enzyme activity was observed for L. mesenteroides NRRL $\mathrm{B}-512 \mathrm{~F}$. The $\mathrm{pH}$ range for maximum enzyme production for Weissella confusa was narrow 5.2-5.6, whereas for $L$. mesenteroides NRRL B-512F, L. mesenteroides NRRL B-640, and P. pentosaceus, it was 6.0-6.5, 4.4-5.9, and 4.0-5.0, respectively.

3.3.3. Analysis and Comparison of Glucan Content of Selected Strain. The cell-free supernatant of isolated strain Weissella confusa (Cab3) gave glucan concentration of $34 \mathrm{mg} / \mathrm{mL}$ (Figure 7). This was very high as compared to other lactic acid bacteria such as from $L$. mesenteroides NRRL B-512F $(6.9 \mathrm{mg} / \mathrm{mL})$ [19], L. mesenteroides NRRL B-640 (7.0 mg/mL) [20], and Pediococcus pentosaceus (10.2 mg/mL) [5]. The glucan concentration of the strain can be further increased by optimizing the medium composition and culture conditions.

3.4. Purification and Identification of Glucansucrase. The enzyme was purified from cell-free supernatant with $1.0 \mathrm{U} / \mathrm{mg}$ specific activity. The fractionation by $33 \%(\mathrm{w} / \mathrm{v})$ PEG-400 gave $10.4 \mathrm{U} / \mathrm{mg}$ specific activity with 10 -fold purification and $26 \%$ overall yield. The purified enzyme showed, approximately, $180 \mathrm{kDa}$ molecular size on the nondenaturing SDS-PAGE gel when stained with Coomassie Brilliant Blue 


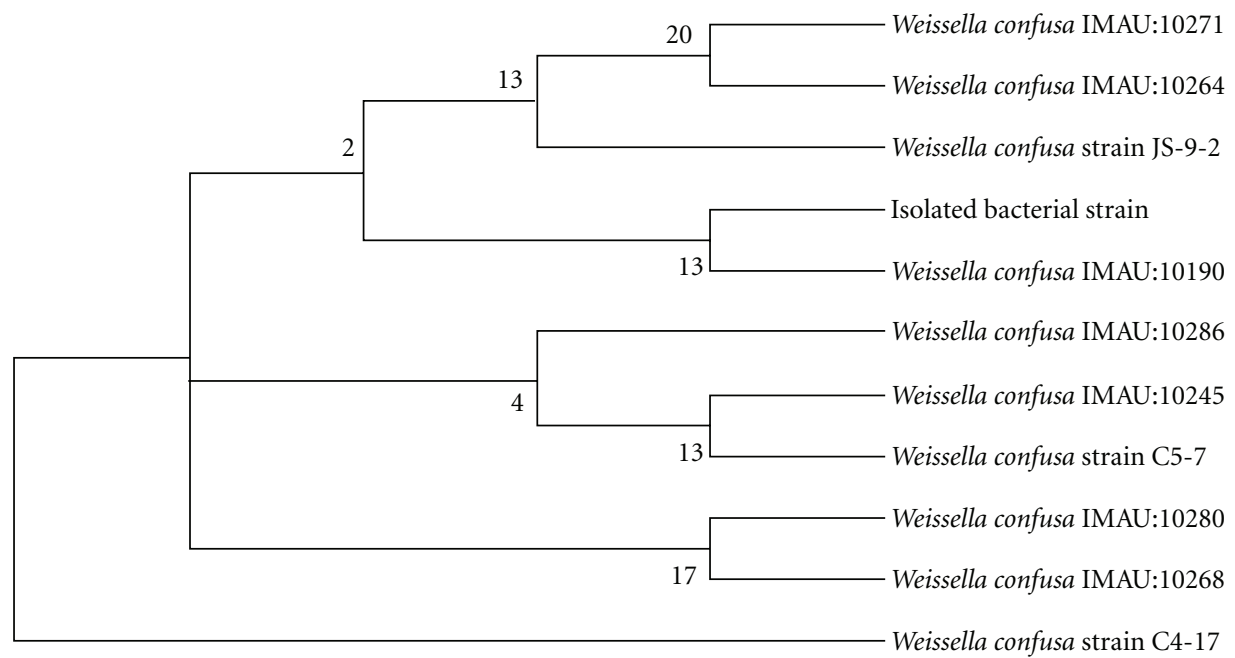

Figure 4: Evolutionary relationships of 11 taxa.

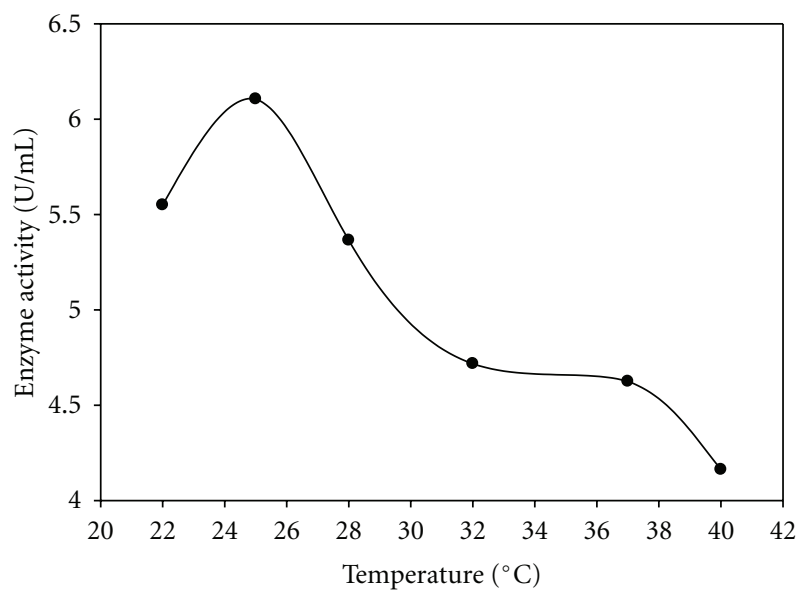

FIGURE 5: Effect of temperature on glucansucrase production from Weissella confusa. The maximum enzyme activity obtained at each temperature was plotted.

(Figure 8; lane 2). The PAS staining of the gel incubated in sucrose (Figure 8; lane 3) showed that the activity band corresponded to the presence of active form of the purified glucansucrase (Figure 8; lane 2). No activity band after PAS staining appeared after the incubation of the nondenaturing SDS-PAGE gel in raffinose (Figure 8; lane 4), thus excluding the presence of fructosyltransferase.

\subsection{Effect of Temperature, $p H$, and Ionic Strength on Enzyme} Activity. The partially purified enzyme was maximally active at the temperature $35^{\circ} \mathrm{C}$, at $\mathrm{pH} 5.4$ in $0.2 \mathrm{mM}$ sodium acetate buffer $\mathrm{pH} 5.4$ (Figure 9). The results showed that the glucansucrase activity was stable within the range of 10 $20 \mathrm{mM}$ (Figure 9). The enzyme lost $41 \%$ of its activity at $50 \mathrm{mM}$. Beyond $50 \mathrm{mM}$, the decrease in the enzyme activity was not significant with the increase of ionic strength. The $\mathrm{pH} 5.4$ was optimum for enzyme activity as shown in

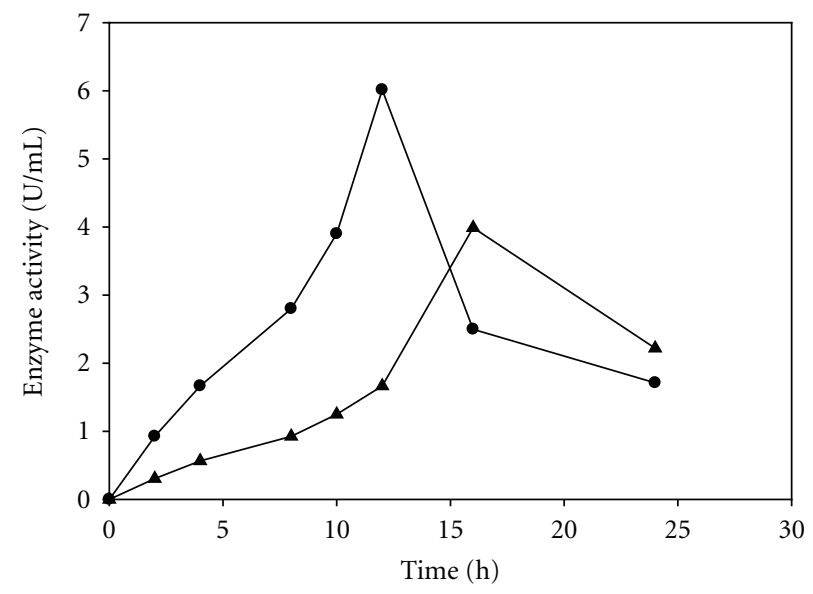

FIGURE 6: Effect of shaken-and static-flask culture on glucansucrase production. Enzyme activity under shaken-(-•-) and static$(-\boldsymbol{\Delta}-)$ ) flask culture is shown.
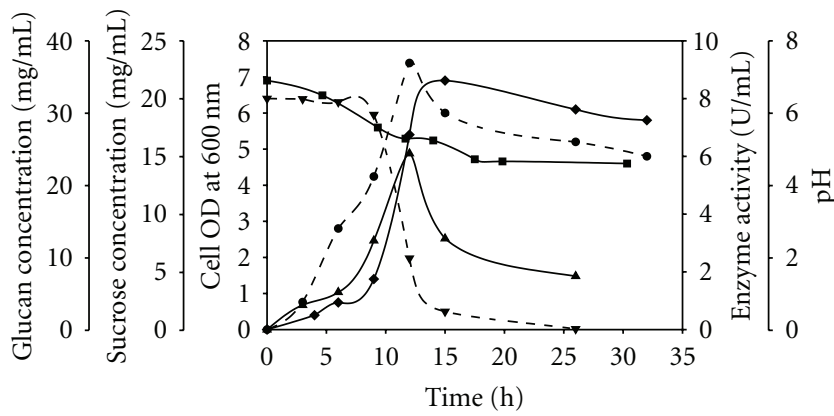

Figure 7: Fermentation profile of Weissella confusa. The enzyme activity (- - ), cell growth $(-\downarrow), \mathrm{pH}(-\mathbf{-}-)$, sucrose conc. (- - - ---$)$ and glucan conc. (-- - - - ) changes are shown.

Figure 9. At $\mathrm{pH}$ below and above 5.4, a sharp decrease in enzyme activity was observed, which has been observed with other glucansucrases [16, 17]. 
TABle 2: Comparison of Weissella confusa with L. mesenteroides NRRL B-512F, L. mesenteroides NRRL B-640 and Pediococcus pentosaceus behavior in flask culture.

\begin{tabular}{|c|c|c|c|c|}
\hline Fermentation parameters & $\begin{array}{l}\text { Weissella } \\
\text { confusa }\end{array}$ & $\begin{array}{l}\text { L. mesenteroides } \\
\text { NRRL B-512F }\end{array}$ & $\begin{array}{l}\text { L. mesenteroides } \\
\text { NRRL B-640 }\end{array}$ & $\begin{array}{c}\text { Pediococcus } \\
\text { pentosaceus } \\
\text { (SPA) }\end{array}$ \\
\hline Duration (h) & 12 & $12[16]$ & 14 [17] & $16[18]$ \\
\hline Maximum enzyme activity $(\mathrm{U} / \mathrm{mL})$ & 6.1 & 4.1 & $4.8[17]$ & $3.4[5]$ \\
\hline $\mathrm{pH}$ range for maximum enzyme production & $5.2-5.6$ & $6.0-6.5[16]$ & $4.4-5.9[17]$ & $4-5[18]$ \\
\hline Temperature $\left({ }^{\circ} \mathrm{C}\right)$ & $25^{\circ} \mathrm{C}$ & $23^{\circ} \mathrm{C}[16]$ & $25^{\circ} \mathrm{C}[17]$ & $25^{\circ} \mathrm{C}[18]$ \\
\hline Cell density $\left(\mathrm{OD}_{600 \mathrm{~nm}}\right)$ & 5.4 & 5.8 & 5.0 & 8.1 \\
\hline Glucan concentration $(\mathrm{mg} / \mathrm{mL})$ & 34 & $6.9[19]$ & $7.0[20]$ & $10.2[5]$ \\
\hline
\end{tabular}

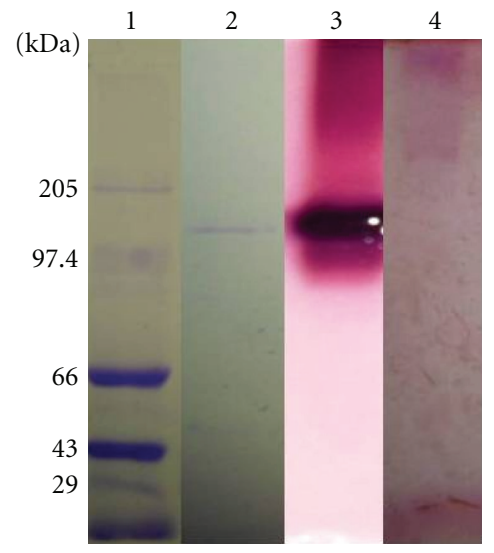

FIGURE 8: Nondenaturing SDS-PAGE analyses using 7\% acrylamide gel. Lane (1) protein molecular weight marker (29-205 kDa), (2) 33\% (w/v) PEG-400 fraction; identification of glucansucrase of purified glucansucrase by staining of glucan formed using: lane (3) Sucrose, (4) raffinose.

\section{Conclusion}

The isolated bacterium (Cab3) was identified at species and genus levels based on $16 \mathrm{~S}$ rDNA sequencing to be Weissella confusa IMAU:10190 (Genbank Accession Number GU 138518.1). The isolated strain could be very promising candidate for glucan production at industrial level as it has high glucan concentration $(34 \mathrm{mg} / \mathrm{mL})$. The physiological and biochemical characterisation was carried out to distinguish the isolate from other closely related lactic acid bacteria. Based on biochemical and physiological studies, the strain showed its relation with other Weissella sp. The strain was resistant to gentamicin, kanamycin, norfloxacin, and vancomycin. The isolate Weissella confusa (Cab3) could not ferment mellibiose, raffinose, and trehalose, a common trait of Weissella confusa. The optimum culture conditions for maximum enzyme production were optimized. The $25^{\circ} \mathrm{C}$ temperature and shaking condition were optimum for enzyme production. The partially purified enzyme was confirmed as glucansucrase by PAS staining of nondenaturing SDS-PAGE gel incubated with sucrose. The presence of fructosyltransferase was ruled out based on the absence of

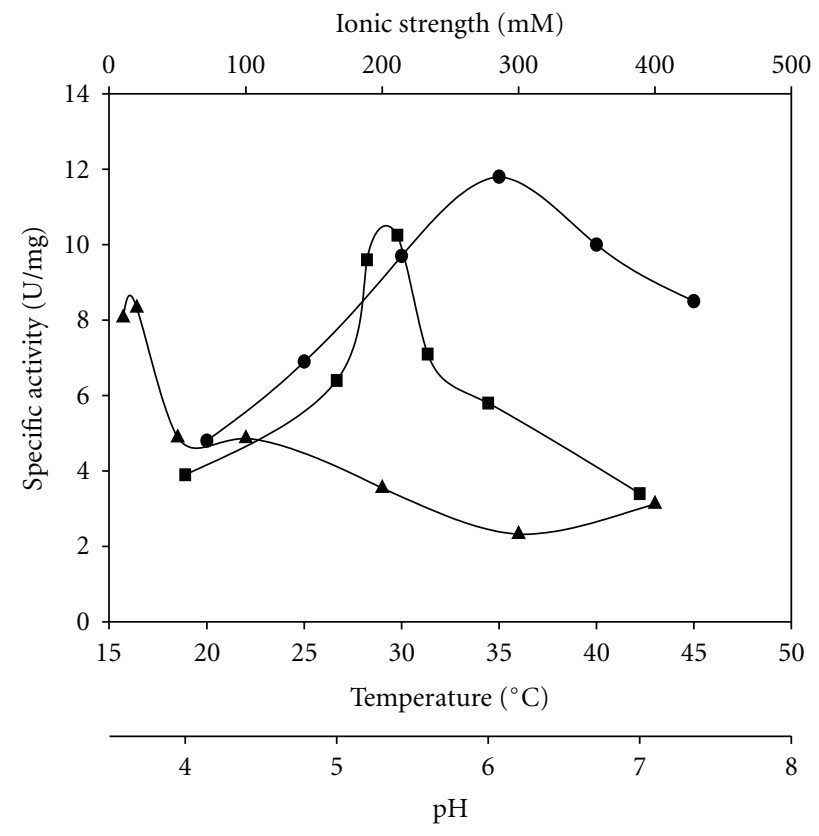

FIGURE 9: Effect of different enzyme assay conditions on specific activity $(\mathrm{U} / \mathrm{mg})$. The effect of ionic strength (- - -), temperature $(-\bullet-)$, and $\mathrm{pH}(-\mathbf{\square}-)$ are shown.

the band in raffinose-incubated nondenaturing SDS-PAGE gel. The partially purified enzyme showed highest activity at $35^{\circ} \mathrm{C}$, when assayed in $20 \mathrm{mM}$ sodium acetate buffer $(\mathrm{pH}$ 5.4). The wide applications of glucan in food, pharmaceutical, and cosmetics industries emphasize the importance of exploration of the new strains and characterization of their traits. This study reveals a novel high glucan producing bacterial isolate which could be a good alternative for glucanproduction in the future.

\section{Acknowledgments}

This research work was supported by a project grant by the Council of Scientific and Industrial Research (CSIR), New Delhi, India, to A. Goyal Fellowship to S. Shukla by Indian Institute of Technology Guwahati is thankfully acknowledged. 


\section{References}

[1] K. Katina, N. H. Maina, R. Juvonen et al., "In situ production and analysis of Weissella confusa dextran in wheat sourdough," Food Microbiology, vol. 26, no. 7, pp. 734-743, 2009.

[2] Y. Lee, "Characterization of Weissella kimchii PL9023 as a potential probiotic for women," FEMS Microbiology Letters, vol. 250, no. 1, pp. 157-162, 2005.

[3] R. L. Sidebotham, "Dextrans," Advances in Carbohydrate Chemistry and Biochemistry, vol. 30, pp. 371-444, 1974.

[4] T. Smitinont, C. Tansakul, S. Tanasupawat et al., "Exopolysaccharide-producing lactic acid bacteria strains from traditional thai fermented foods: isolation, identification and exopolysaccharide characterization," International Journal of Food Microbiology, vol. 51, no. 2-3, pp. 105-111, 1999.

[5] S. Patel, N. Kasoju, U. Bora, and A. Goyal, "Structural analysis and biomedical applications of dextran produced by a new isolate Pediococcus pentosaceus screened from biodiversity hot spot Assam," Bioresource Technology, vol. 101, no. 17, pp. 6852-6855, 2010.

[6] M. D. Collins, J. Samelis, J. Metaxopoulos, and S. Wallbanks, "Taxonomic studies on some leuconostoc-like organisms from fermented sausages: description of a new genus Weissella for the Leuconostoc paramesenteroides group of species," Journal of Applied Bacteriology, vol. 75, no. 6, pp. 595-603, 1993.

[7] N. H. Maina, M. Tenkanen, H. Maaheimo, R. Juvonen, and L. Virkki, "NMR spectroscopic analysis of exopolysaccharides produced by Leuconostoc citreum and Weissella confusa," Carbohydrate Research, vol. 343, no. 9, pp. 1446-1455, 2008.

[8] F. Villani, G. Moschetti, G. Blaiotta, and S. Coppola, "Characterisation of strains of Leuconostoc mesenteroides by analysis of soluble whole-cell protein pattern, DNA fingerprinting and restriction of ribosomal DNA," Journal of Applied Microbiology, vol. 82, no. 5, pp. 578-588, 1997.

[9] J. Samelis, J. Rementzis, E. Tsakalidou, and J. Metaxopoulos, "Usefulness of rapid GC analysis of cellular fatty acids for distinguishing Weissella viridescens, Weissella paramesenteroides, Weissella hellenica and some non-identifiable, arginine-negative Weissella strains of meat origin," Systematic and Applied Microbiology, vol. 21, no. 2, pp. 260-265, 1998.

[10] P. Kurzak, M. A. Ehrmann, and R. F. Vogel, "Diversity of lactic acid bacteria associated with ducks," Systematic and Applied Microbiology, vol. 21, no. 4, pp. 588-592, 1998.

[11] F. Ampe, N. ben Omar, C. Moizan, C. Wacher, and J. P. Guyot, "Polyphasic study of the spatial distribution of microorganisms in Mexican pozol, a fermented maize dough, demonstrates the need for cultivation-independent methods to investigate traditional fermentations," Applied and Environmental Microbiology, vol. 65, no. 12, pp. 5464-5473, 1999.

[12] P. Kurzak, M. A. Ehrmann, and R. F. Vogel, "Diversity of lactic acid bacteria associated with ducks," Systematic and Applied Microbiology, vol. 21, no. 4, pp. 588-592, 1998.

[13] J. C. De Man, M. Rogosa, and M. E. Sharpe, "A medium for the cultivation of lactobacilli," Journal of Applied Bacteriology, vol. 23, pp. 130-135, 1960.

[14] A. Goyal and S. S. Katiyar, "Regulation of dextransucrase productivity of Leuconostoc mesenteroides NRRL B-512F by the maintenance media," Journal of General and Applied Microbiology, vol. 42, no. 1, pp. 81-85, 1996.

[15] T. Gregersen, "Rapid method for distinction of gram negative from gram positive bacteria," European Journal of Applied Microbiology, vol. 5, no. 2, pp. 123-127, 1978.
[16] A. Goyal, M. Nigam, and S. S. Katiyar, "Optimal conditions for production of dextransucrase from Leuconostoc mesenteroides NRLL B-512F and its properties," Journal of Basic Microbiology, vol. 35, no. 6, pp. 375-384, 1995.

[17] R. K. Purama and A. Goyal, "Optimization of conditions of Leuconostoc mesenteroides NRRL b-640 for production of a dextransucrase and its assay," Journal of Food Biochemistry, vol. 33, no. 2, pp. 218-231, 2009.

[18] S. Patel and A. Goyal, "Isolation, characterization and mutagenesis of exopolysaccharide synthesizing new strains of lactic acid bacteria," Internet Journal of Microbiology, vol. 8, no. 1, pp. 3-4, 2010.

[19] M. Santos, J. Teixeira, and A. Rodrigues, "Production of dextransucrase, dextran and fructose from sucrose using Leuconostoc mesenteroides NRRL B512(f)," Biochemical Engineering Journal, vol. 4, no. 3, pp. 177-188, 2000.

[20] A. Majumder, S. Bhandari, R. K. Purama, S. Patel, and A. Goyal, "Enhanced production of a novel dextran from Leuconostoc mesenteroides NRRL B-640 by response surface methodology," Annals of Microbiology, vol. 59, no. 2, pp. 309315, 2009.

[21] O. Kandler and N. Weiss, "Genus Lactobacillus beijerinck 1901, 212AL," in Bergey's Manual of Systematic Bacteriology, P. H. A. Sneath, N. S. Mair, M. E. Sharpe, and J. G. Holt, Eds., vol. 2, pp. 1209-1234, Williams and Wilkins, Baltimore, Md, USA, 1986.

[22] A. L. Barry and C. Thornsberry, "Susceptibility testing: diffusion procedures," in Manual of Clinical Microbiology, E. H. Lennette, A. Balows, W. J. Hausler Jr., and J. P. Truant, Eds., pp. 463-474, American Society for Microbiology, Washington, DC, USA, 1980.

[23] D. G. Pitcher, N. A. Saunders, and R. J. Owen, "Rapid extraction of bacterial genomic DNA with guanidium thiocyanate," Letters in Applied Microbiology, vol. 8, no. 4, pp. 151-156, 1989.

[24] J. Magnusson, H. Jonsson, J. Schnürer, and S. Roos, "Weissella soli sp. nov., a lactic acid bacterium isolated from soil," International Journal of Systematic and Evolutionary Microbiology, vol. 52, no. 3, pp. 831-834, 2002.

[25] H. J. Choi, C. I. Cheigh, S. B. Kim et al., "Weissella kimchii sp. nov., a novel lactic acid bacterium from kimchi," International Journal of Systematic and Evolutionary Microbiology, vol. 52, no. 2, pp. 507-511, 2002.

[26] S. Tanasupawat, O. Shida, S. Okada, and K. Komagata, "Lactobacillus acidipiscis sp. nov. and Weissella thailandensis sp. nov., isolated from fermented fish in Thailand," International Journal of Systematic and Evolutionary Microbiology, vol. 50, no. 4, pp. 1479-1485, 2000.

[27] R. K. Purama, M. Agrawal, A. Majumder, S. Ahmed, and A. Goyal, "Antibiotic sensitivity, carbohydrate fermentation characteristics, and plasmid profiles of glucansucrase producing four Leuconostoc strains," Journal of Pure and Applied Microbiology, vol. 2, no. 1, pp. 139-146, 2008.

[28] K. Tamura, J. Dudley, M. Nei, and S. Kumar, "MEGA4: Molecular Evolutionary Genetics Analysis (MEGA) software version 4.0," Molecular Biology and Evolution, vol. 24, no. 8, pp. 1596-1599, 2007.

[29] N. Nelson, "A photometric adaptation of the Somoyogi method for the determination of glucose," The Journal of Biological Chemistry, vol. 153, pp. 375-380, 1944.

[30] M. Somogyi, "A new reagent for the determination of sugars," The Journal of Biological Chemistry, vol. 160, pp. 61-68, 1945. 
[31] H. M. Tsuchiya, H. J. Koepsell, J. Corman et al., "The effect of certain cultural factors on production of dextransucrase by Leuconostoc mesenteroides," Journal of Bacteriology, vol. 64, no. 4, pp. 521-526, 1952.

[32] M. Dubois, K. A. Gilles, J. K. Hamilton, P. A. Rebers, and F. Smith, "Colorimetric method for determination of sugars and related substances," Analytical Chemistry, vol. 28, no. 3, pp. 350-356, 1956.

[33] J. D. Fox and J. F. Robyt, "Miniaturization of three carbohydrate analyses using a microsample plate reader," Analytical Biochemistry, vol. 195, no. 1, pp. 93-96, 1991.

[34] O. H. Lowry, N. J. Rosebrough, A. L. Farr, and R. J. Randall, "Protein measurement with the Folin phenol reagent," The Journal of Biological Chemistry, vol. 193, no. 1, pp. 265-275, 1951.

[35] T. Vasileva, A. Kirilov, V. Bivolarski,, M. S. Bounaix, and V. Gabriel, "Characterisation of glucansucrase activities from Leuconostoc mesenteroides Lm 17 and Ure 13," Biotechnology and Biotechnological Equipment, vol. 23, pp. 698-701, 2009.

[36] U. K. Laemmli, "Cleavage of structural proteins during the assembly of the head of bacteriophage T4," Nature, vol. 227, no. 5259 , pp. 680-685, 1970.

[37] R. Patel, F. R. Cockerill, M. K. Porayko, D. R. Osmon, D. M. Ilstrup, and M. R. Keating, "Lactobacillemia in liver transplant patients," Clinical Infectious Diseases, vol. 18, no. 2, pp. 207212, 1994.

[38] M. Green, K. Barbadora, and M. Michaels, "Recovery of vancomycin-resistant gram-positive cocci from pediatric liver transplant recipients," Journal of Clinical Microbiology, vol. 29, no. 11, pp. 2503-2506, 1991.

[39] A. Olano, J. Chua, S. Schroeder, A. Minari, M. La Salvia, and G. Hall, "Weissella confusa (Basonym: Lactobacillus confusus) bacteremia: a case report," Journal of Clinical Microbiology, vol. 39, no. 4, pp. 1604-1607, 2001.

[40] J. Y. Liu, A. H. Li, C. Ji, and W. M. Yang, "First description of a novel Weissella species as an opportunistic pathogen for rainbow trout Oncorhynchus mykiss (Walbaum) in China," Veterinary Microbiology, vol. 136, no. 3-4, pp. 314-320, 2009.

[41] M. Casanellas and J. Fernández-Sánchez, "Geometry of the Kimura 3-parameter model," Advances in Applied Mathematics, vol. 41, no. 3, pp. 265-292, 2008.

[42] N. Saitou and M. Nei, "The neighbor-joining method: a new method for reconstructing phylogenetic trees," Molecular Biology and Evolution, vol. 4, no. 4, pp. 406-425, 1987.

[43] J. Felsenstein, "Confidence limits on phylogenies: an approach using the bootstrap," Evolution, vol. 39, pp. 783-791, 1985.

[44] M. Kimura, "A simple method for estimating evolutionary rates of base substitutions through comparative studies of nucleotide sequences," Journal of Molecular Evolution, vol. 16, no. 2, pp. 111-120, 1980. 

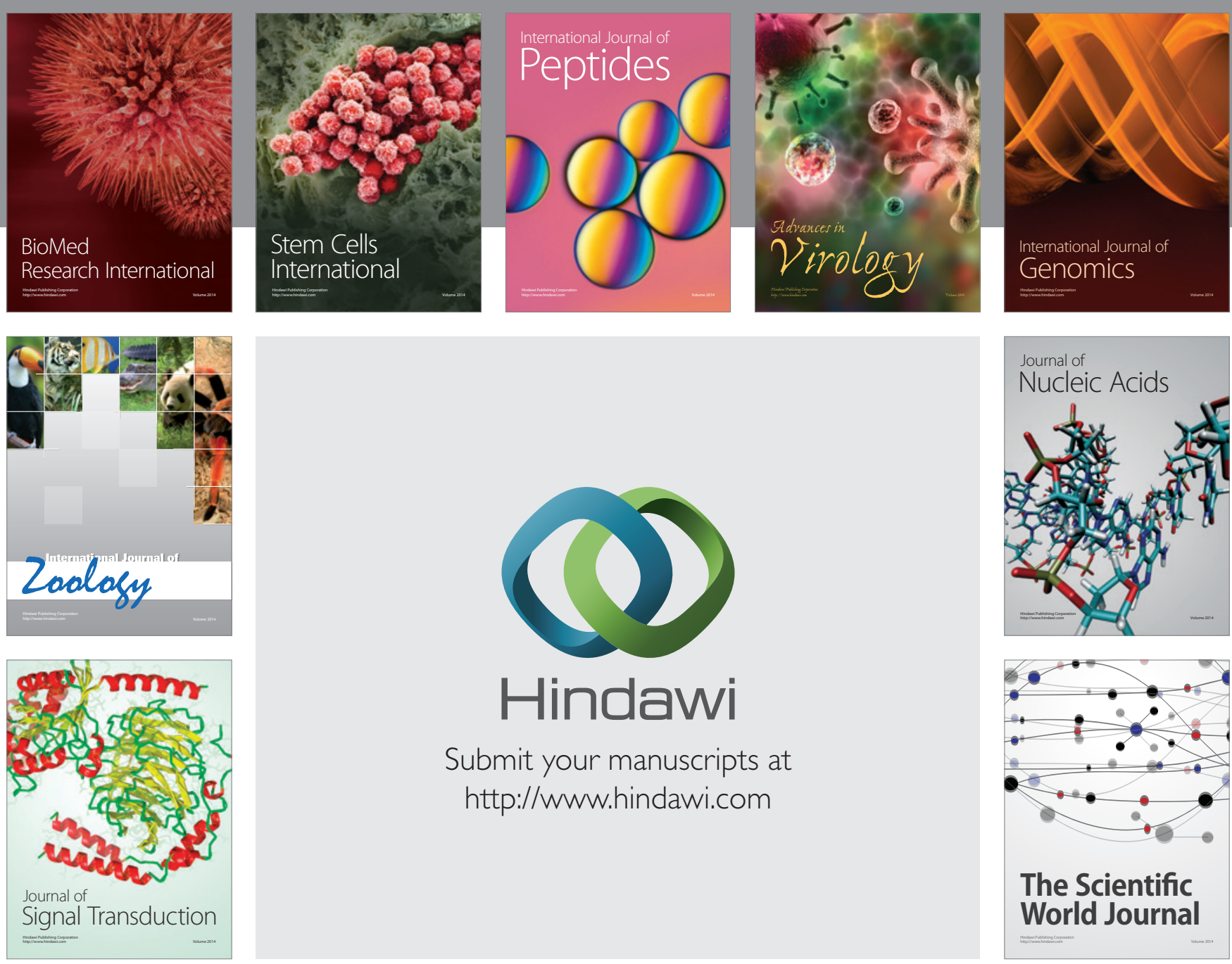

Submit your manuscripts at

http://www.hindawi.com
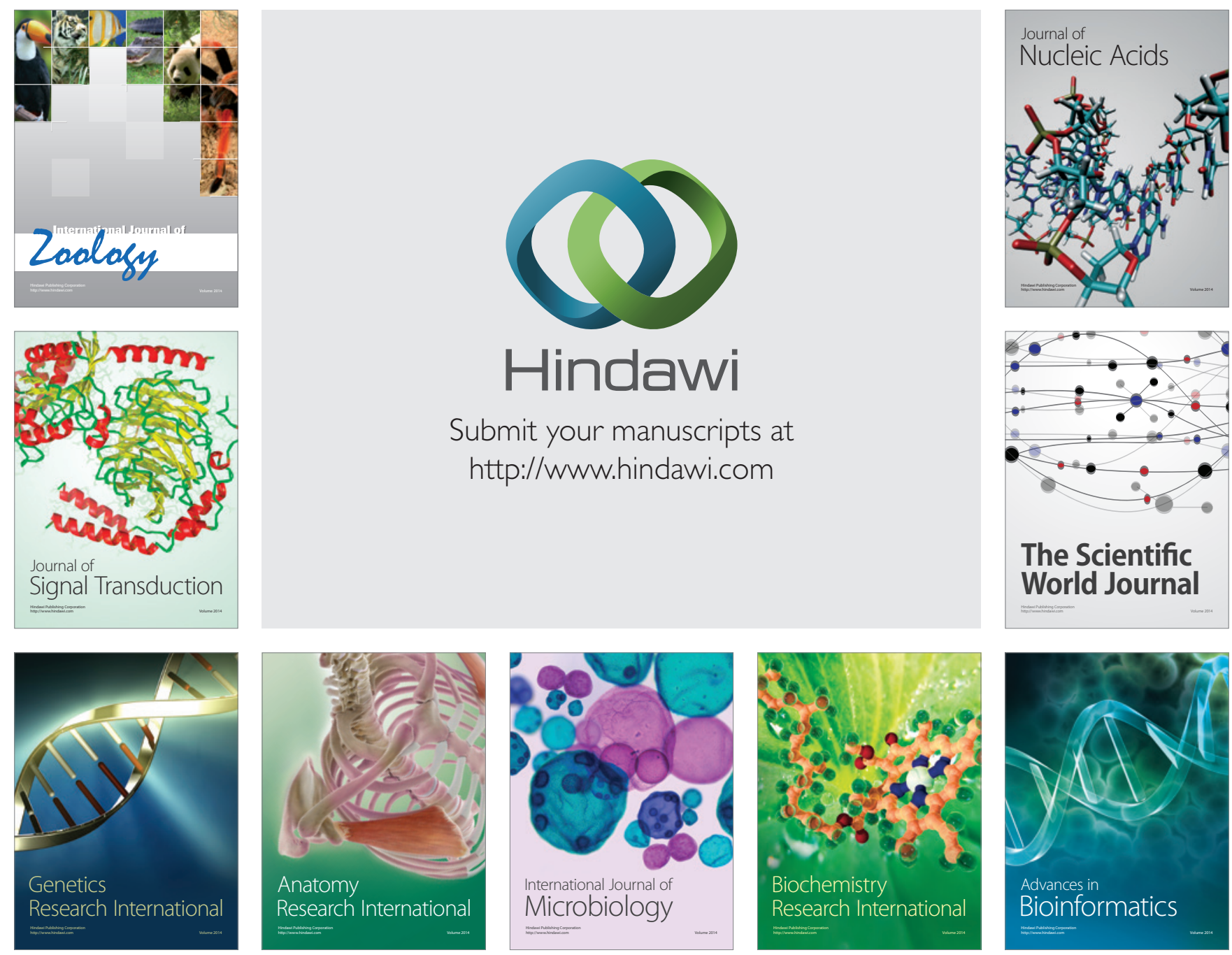

The Scientific World Journal
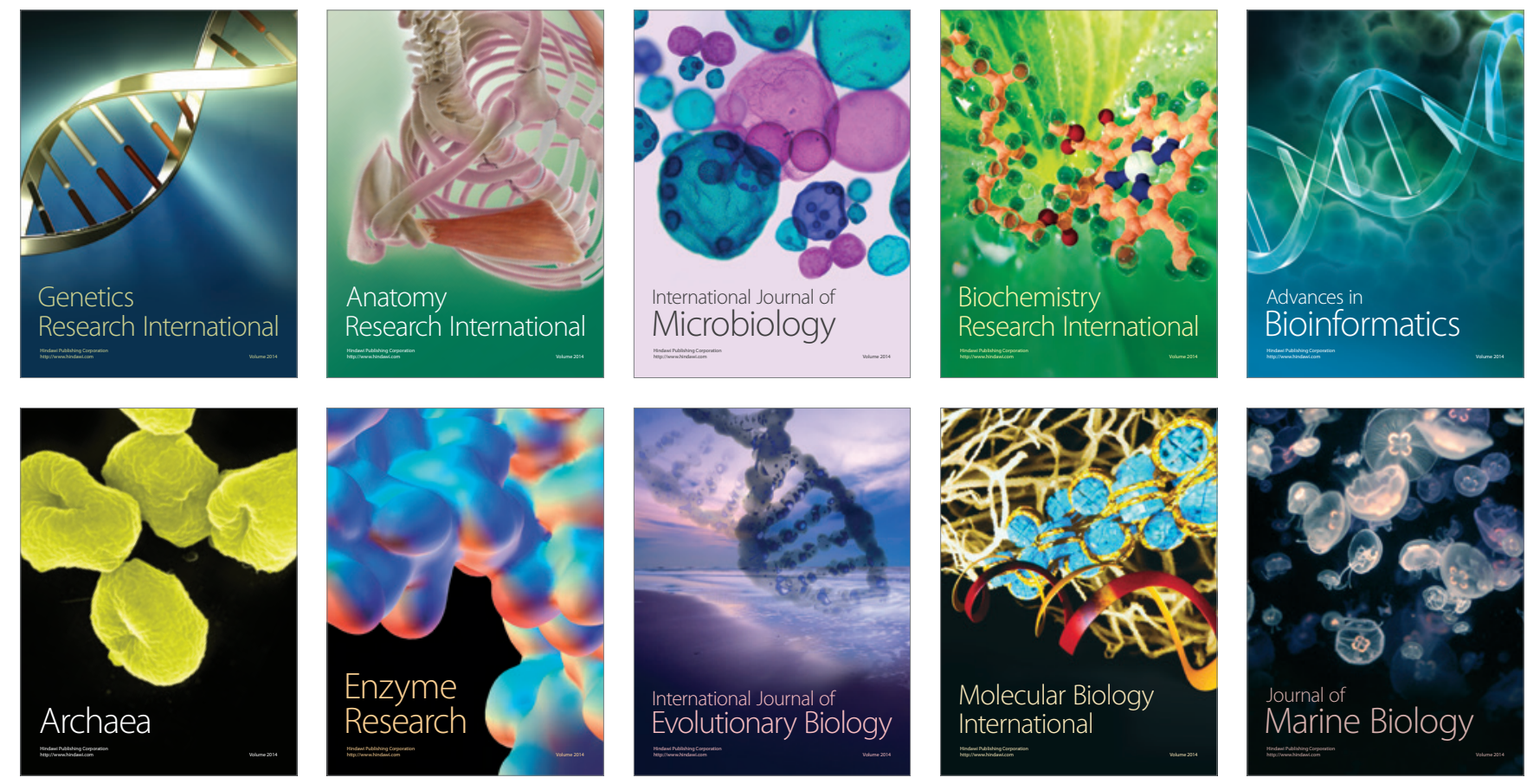